\title{
NSILA-Carrier Protein Abolishes the Action of Nonsuppressible Insulin-Like Activity (NSILA-S) on Perfused Rat Heart
}

\author{
C. Meuli, J. Zapf, and E. R. Froesch \\ Metabolic Unit, Department of Medicine, Kantonsspital Zürich, Switzerland
}

Summary. Human serum in a concentration of $10 \%$ in the perfusion medium failed to increase glucose uptake by the isolated perfused rat heart, indicating that nonsuppressible insulin-like activity (NSILA) in whole serum was inactive in this system. When NSILA-carrier protein was added to partially purified NSILA-S, its biological activity on the rat heart disappeared. In contrast, the action of insulin was not affected by the presence of NSILA-carrier protein. Binding of ${ }^{125}$ I-labelled NSILA-S to rat heart was inhibited by NSILA-carrier protcin. ${ }^{125} \mathrm{I}$ labelled insulin binding was not inhibited. These results support the hypothesis that NSILA-S bound to serum carrier protein is a large molecular compound which does not readily diffuse out of the capillary bed and therefore does not exert insulin-like effects in vivo.

Key words: Nonsuppressible insulin-like activity, NSILA-carrier protein, human serum, perfused rat heart, glucose uptake, hormone binding.

Human serum exerts insulin-like activity on tissues in vitro which is not suppressed by the addition of insulin antibodies [1]. This activity had been shown to reside in a low molecular weight peptide fraction extracted with acid-ethanol (NSILA-S ${ }^{1}$, mol. wt. 7500, R. E. Humbel, personal communication) [2, 3]. Further purification resolved NSILA-S into two closely related molecular species which exert almost

\footnotetext{
1 NSILA: nonsuppressible insulin-like activity of native human serum

NSILA-S: nonsuppressible insulin-like activity extracted from human serum with acid-cthanol
}

identical biological effects [4]. The partial amino acid sequence of these two species has been elucidated [5].

It has been puzzling for a long time why NSILA in its native form in blood does not exert insulin-like effects in vivo. A possible explanation was provided by the finding that serum contains a specific high molecular weight carrier protein to which NSILA is tightly bound $[6,7]$. The hypothesis was advanced that capillaries constitute a diffusion barrier for the NSILA-carrier-complex and, therefore, prevent its contact with cells.

This hypothesis was tested in the perfused rat heart which is an experimental model in which the biological effects of NSILA-S have been well defined $[8,9,10]$ and in which hormones reach the target cells via an intact vascular system.

\section{Materials}

Partially purified NSILA-S (3.8 $\mathrm{mU} / \mathrm{mg})$ and whale insulin $(24 \mathrm{U} / \mathrm{mg}$ ) (identical to pork insulin) were kindly supplied by Drs. E. Rinderknecht and R. E. Humbel. The NSILA-S preparation used was a mixture of NSILA-S I and NSILA-S II [4]. Molar concentrations of NSILA-S were calculated on the basis of a mol.wt. of 7500 and a specific biological activity of $400 \mathrm{mU} / \mathrm{mg}$ for both forms as determined in the fat pad assay with insulin as the reference [4]. ${ }^{125}$ I-labelled NSILA-S was prepared according to Zapf et al. [11]. ${ }^{125}$ I-labelled insulin was purchased from CIS (Italy) (specific radioactivity $84 \mathrm{mCi} / \mathrm{mg}$ ). Heparin (Liquemin) was from ROCHE, Switzerland (5000 USP-U/ml). Human serum albumin, devoid of insulin-like activity, was purchased from the Swiss Red Cross, Berne. Guinea pig anti-insulin serum had an insulin neutralizing capacity of $1 \mathrm{U} / \mathrm{ml}$. 


\section{Methods}

\section{Human Serum}

Venous blood was taken from normal subjects after an overnight fast. One hour at $4^{\circ} \mathrm{C}$ was chosen for clotting. After centrifugation, the serum was pooled and stored at $-20^{\circ} \mathrm{C}$.

\section{NSILA-Carrier Protein}

Serum carrier protein for NSILA-S was partially purified according to Zapf et al. [6]. Human serum $(60 \mathrm{ml})$ was applied to a column of Sephadex G-200 (total bed volume 31 ), equilibrated with acetic acid $0.15 \mathrm{~mol} / 1$ and $\mathrm{NaCl} 0.15 \mathrm{~mol} / \mathrm{l}$. The column effluent between $60 \%$ and $80 \%$ of the total bed volume was separated into two pools and concentrated by ultrafiltration. The concentrated pools were dialysed extensively against bicarbonate buffer of the same composition as that used for heart perfusion [9]. Relative binding activity for ${ }^{125}$ I-labelled NSILA-S was determined according to Zapf et al. [6]. The two pools had binding activities for ${ }^{125}$ I-labelled NSILA$\mathrm{S}$ of approximately $8 \mathrm{mU} / 1\left(3 \times 10^{-9} \mathrm{~mol} / \mathrm{l}\right)$ and 30 $\mathrm{mU} / 1\left(1 \times 10^{-8} \mathrm{~mol} / \mathrm{l}\right)$. For each glucose uptake experiment $1.5 \mathrm{ml}$ of the pool with the higher binding activity was used. The pool $(1.5 \mathrm{ml})$ with the lower binding activity was used for the membrane binding experiments.

\section{Perfusion Experiments}

Hearts of fed male ZBZ Cara (formerly OsborneMendel) rats were perfused with Krebs-Ringer bicarbonate buffer gassed with $95 \% \mathrm{O}_{2} / 5 \% \mathrm{CO}_{2}, \mathrm{pH} 7.4$. The technique applied for rat heart perfusion together with some basic metabolic reference data have been reported previously $[8,9]$. Glucose uptake by the perfused rat heart and binding of ${ }^{125}$ I-labelled hormones were determined as described earlier $[9$, 10].

Perfusion with human serum was performed in the presence of heparin (83 USP-U/ml) to prevent formation of fibrin.

NSILA-carrier protein $(1.5 \mathrm{ml})$ was preincubated for two hours at room temperature with the labelled or unlabelled hormones prior to the perfusion experiment in order to reach binding equilibrium [12]. Krebs-Ringer bicarbonate buffer containing glucose $10 \mathrm{mmol} / 1$ and human serum albumin $2 \mathrm{~g} / \mathrm{l}$ was then added to a final volume of $25 \mathrm{ml}$. The quantity of serum carrier protein required for nearly complete binding of NSILA-S was estimated from the relative binding activities as determined in experiments using ${ }^{125}$ I-labelled NSILA-S [12].
All experiments with the labelled hormones were carried out in pairs using the same perfusion fluid, one with and one without added NSILA-carrier protein. Inhibition of membrane binding by NSILA-carrier protein was calculated as per cent of the control. Nonspecific binding was not determined since the large amounts of unlabelled NSILA-S that would have been required were not available. All results are given as means \pm Standard Error of the Mean (SEM). Student's t-test was used for statistical evaluation.

\section{Results}

Human serum, diluted ten times with Krebs-Ringer bicarbonate buffer, did not significantly increase glucose uptake by the perfused rat heart above the values obtained in the presence of heparin alone $(\mathrm{p}>$ 0.40 ) (Fig. 1). The NSILA content of $10 \%$ human serum $\left(10-20 \mathrm{mU} / 1,7 \times 10^{-9} \mathrm{~mol} / \mathrm{l}\right)$ [13] would have been high enough to elicit a near maximal response (glucose uptake in the presence of NSILAS $20 \mathrm{mU} / \mathrm{l}: 185 \pm 9 \mu \mathrm{mol} \times \mathrm{g}$ dry wt. ${ }^{-1} \times \mathrm{h}^{-1}$, $\mathrm{n}=4$ ). The small amount of insulin present in human serum was neutralized by the addition of guinea pig anti-insulin serum. Heparin itself showed a slight insulin-like effect. The response of the rat heart to insulin and NSILA-S was not changed by heparin.

In the next series of experiments, the rat heart was perfused with NSILA-S in the presence and absence of NSILA-carrier protein. Serum binding protein by itself did not exert insulin-like activity. The results are shown in Figure 2. NSILA-S at a concentration of $7 \times 10^{-10} \mathrm{~mol} / 1(2 \mathrm{mU} / 1)$ significantly increased glucose uptake. The carrier protein abolished the effect of NSILA-S. This inhibition was statistically significant $(\mathrm{p}<0.005)$.

Figure 3 shows that the action of insulin was not inhibited by the addition of NSILA-carrier protein $(\mathrm{p}>0.5)$.

Experiments with ${ }^{125}$ I-labelled NSILA-S showed that its binding to rat heart was inhibited by about $40 \%$ in the presence of NSILA-carrier protein (Table 1). Binding of ${ }^{125}$ I-labelled insulin was inhibited only by $10 \%$. The difference between the inhibition of binding of NSILA-S and insulin was statistically significant $(\mathrm{p}<0.01)$. The ten per cent decrease of insulin binding may be explained by nonspecific adsorption to the serum carrier protein fraction during preincubation.

\section{Discussion}

Since the first reports on nonsuppressible insulin-like activity of human serum, the paradoxical finding that normal serum contained between 100 and $200 \mu \mathrm{U} /$ 


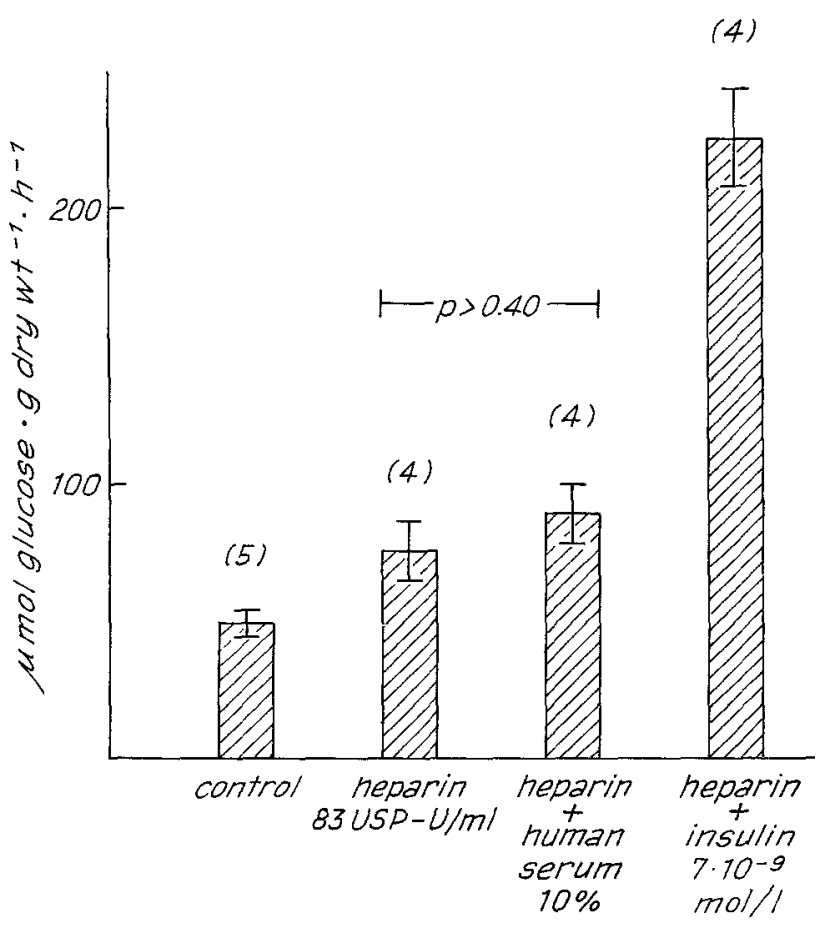

Fig. 1. Effect of diluted human serum $(1: 10)$ and insulin $(7 \times$ $\left.10^{-9} \mathrm{~mol} / \mathrm{l}, 1 \mathrm{U} / \mathrm{l}\right)$ on glucose uptake by the perfused rat heart. NSILA content of $10 \%$ serum: $20 \mathrm{mU} / 1\left(7 \times 10^{-9} \mathrm{~mol} / 1\right)$ [13]. Glucose uptake was expressed as $\mu \mathrm{mol}$ glucose consumed per g dry heart weight per hour. Heparin ( $83 \mathrm{USP}-\mathrm{U} / \mathrm{ml}$ ) was added to prevent formation of fibrin. Guinea pig anti-insulin serum was present in the experiments with human serum (insulin neutralizing capacity in the perfusion fluid: $2 \mathrm{U} / \mathrm{l}$ )

Table 1. Binding of ${ }^{125} \mathrm{I}$-labelled NSILA-S $\left(4 \times 10^{-11} \mathrm{~mol} / \mathrm{l}\right)$ and of ${ }^{125} \mathrm{I}$-labelled insulin $\left(1 \times 10^{-10} \mathrm{~mol} / \mathrm{l}\right)$ to perfused rat heart in the presence of NSILA-carrier protein (relative binding activity for NSILA-S in the perfusion fluid: $1.6 \times 10^{-10} \mathrm{~mol} / 1$ ). Total bound radioactivity was expressed as per cent of control experiments without added serum carrier protein. Non-specific binding was not determined

\begin{tabular}{ll}
\hline & $\begin{array}{l}\text { Bound }{ }^{125} \text { I-labelled } \\
\text { NSILA-S } \% \text { of total binding } \\
\text { insulin }\end{array}$ \\
\hline $\begin{array}{l}\text { Serum carrier } \\
\text { protein added }\end{array}$ & $63.8 \pm 4.3(4)$ \\
\hline
\end{tabular}

$\mathrm{ml}$ of non-immunoreactive insulin equivalents without causing hypoglycaemia remained unexplained [13]. Rasio et al. [14] found that concentrations of immunoreactive insulin (IRI) were similar in rat serum and lymph. In contrast, the concentration of insulin-like activity (ILA) in serum was higher than in lymph. Furthermore, they found that ILA of rat serum and NSILA of dog serum were of high

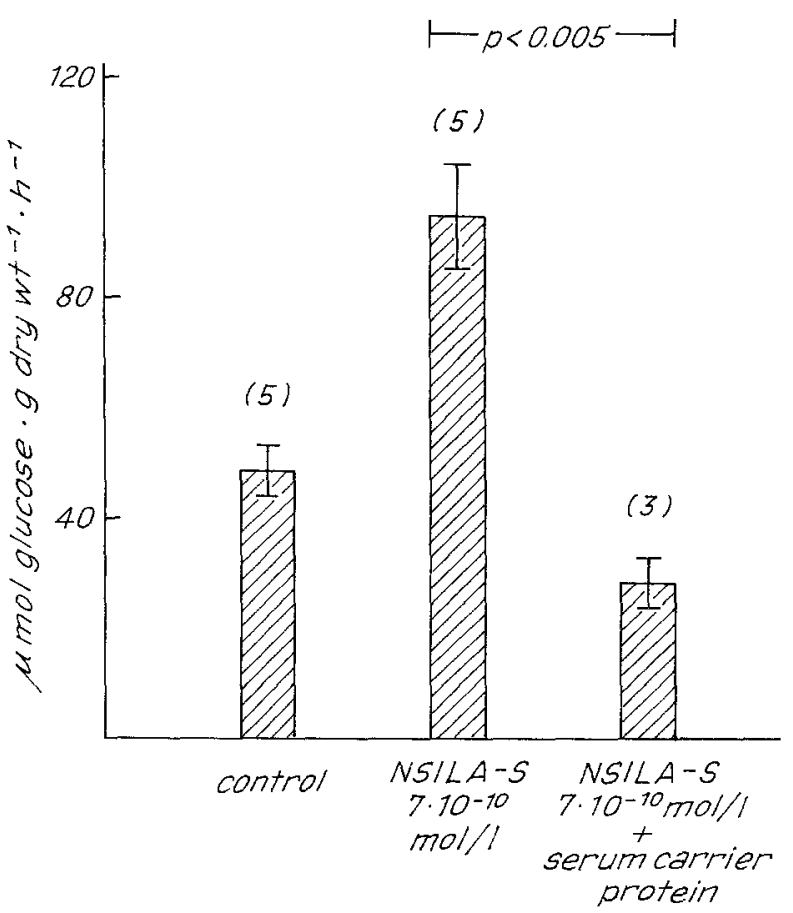

Fig. 2. Effect of NSILA-carrier protein (relative binding activity for NSILA-S in the perfusion fluid: $\left.7 \times 10^{-10} \mathrm{~mol} / \mathrm{l}\right)$ on the stimulation of glucose uptake by the perfused rat heart with NSILA-S, $7 \times 10^{-10} \mathrm{~mol} / 1(2 \mathrm{mU} / \mathrm{l})$

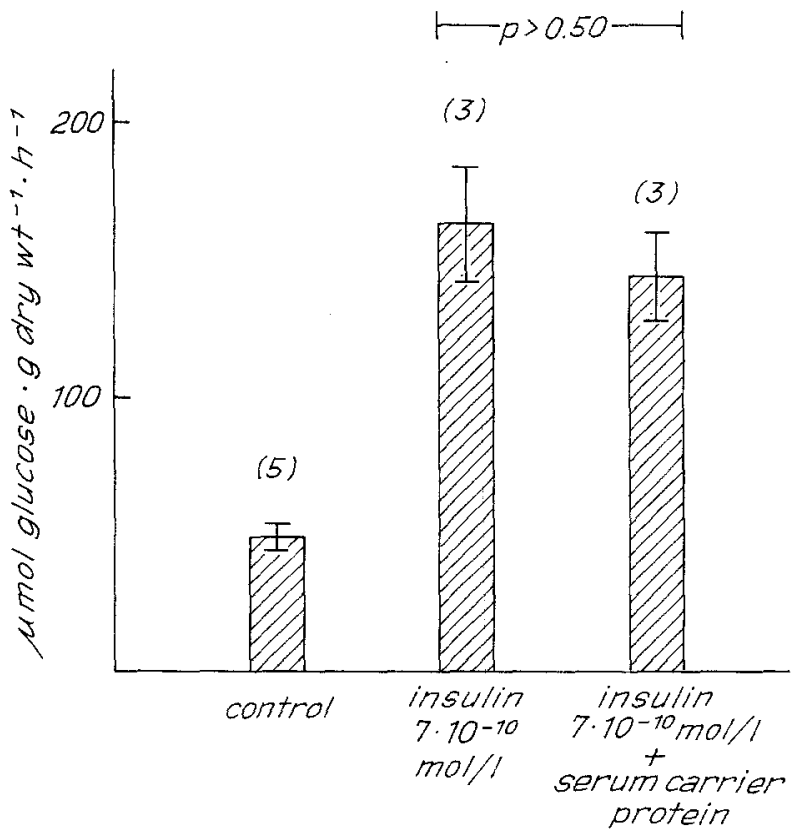

Fig. 3. Effect of NSILA-carrier protein (relative binding activity for NSILA-S in the perfusion fluid: $\left.7 \times 10^{-10} \mathrm{~mol} / 1\right)$ on the stimulation of glucose uptake by the perfused rat heart with insulin, $7 \times 10^{-10} \mathrm{~mol} / \mathrm{l}(100 \mathrm{mU} / \mathrm{l})$ 
molecular weight $[15,16]$. From these results they concluded that NSILA could not diffuse freely from serum to lymph and that it was therefore inactive [16]. Cohen and Nissley [17] demonstrated that rat lymph contained about one-half of the somatomedinlike activity present in serum. Somatomedins belong to the same group of serum peptides with insulin-like activity as NSILA-S.

Bürgi et al. [18] found that after gel filtration of human serum on Sephadex G-200 in ammonium acetate $0.1 \mathrm{~mol} / 1$ ( $\mathrm{pH} 7.2)$, nonsuppressible insulin-like activity eluted with a molecular weight between 70000 and $150000 .{ }^{125}$ I-labelled NSILA-S injected intravenously into rats was preferentially bound to a serum fraction of approximately $200000 \mathrm{~mol}$. wt. [19]. By using dextran particles of various sizes, Garlick et al. [20] demonstrated that particles with a molecular weight larger than 40000 did not rapidly leave the vascular system under normal conditions.

Whereas NSILA-S injected into rats was hypoglycaemic [21], endogenous NSILA did not appear to have any effects on glucose homeostasis. Thus, the hypothesis was put forward that native NSILA with a molecular weight between 70000 and 150000 might not readily penetrate the blood vessels and that its bioavailability might, therefore, be restricted [18, 22]. This hypothesis was supported when serum carrier protein for NSILA-S was detected [6,7]. It was again suggested that the bound form of NSILA-S did not pass the capillary walls and, therefore, was inactive in vivo $[6,19]$. The insulin-like activity of whole serum could only be measured in test systems devoid of an intact vascular system as for example in the epididymal fat pad of the rat [13].

The hypothesis of restricted bioavailability of endogenous NSILA was now tested in the isolated perfused rat heart. This test system provided an organ with an intact vascular network. Moreover, the interaction of NSILA-S with the perfused rat heart has been extensively studied $[8,9,10]$.

The finding that human serum did not stimulate the glucose uptake of perfused rat heart (Figure 1) was in accord with the above hypothesis. Although human serum was diluted ten times, the concentration of NSILA would still have been high enough to elicit a near maximal response $[8,13]$.

Further support for the hypothesis stated above was obtained from the results of the experiments shown in Figures 2 and 3 , in which the effects of NSILA-S and insulin in the presence and absence of NSILA-carrier protein on the perfused rat heart were compared. In the presence of carrier protein, NSILA-S did not stimulate glucose uptake. The effect of a comparable concentration of insulin was not inhibited by the carrier protein.
In the presence of NSILA-carrier protein, less ${ }^{125}$ I-labelled NSILA-S was bound to the heart than in its absence (Table 1). This finding indicated that ${ }^{125} \mathrm{I}-$ labelled NSILA-S, once bound to serum carrier protein, did not considerably dissociate and that its access to the NSILA-S binding sites on the cell membrane was limited. Binding of ${ }^{125} \mathrm{I}$-labelled insulin to the heart was not significantly affected by the presence of NSILA-carrier protein.

All these results are compatible with the hypothesis that NSILA-S bound to carrier protein does not readily diffuse through the capillary walls and that it is therefore inactive in vivo. Our results now provide a plausible answer to the question why normoglycaemia is compatible with the presence of 100 to $200 \mu \mathrm{U}$ of insulin equivalents per ml of human serum.

Acknowledgements. We thank Prof. R. E. Humbel and Dr. E. Rinderknecht for generous supply of NSILA-S and Ms. I. Sand and Ms. G. A. Jagars for their technical assistance. This work was supported by grant Nr.3.595 - 0.75 from the Swiss National Science Foundation.

\section{References}

1. Froesch, E. R., Bürgi, H., Müller, W.A., Humbel, R.E., Jakob, A., Labhart, A.: Nonsuppressible insulinlike activity of human serum: Purification, physicochemical and biological properties and its relation to total serum ILA. Recent Prog. Horm. Res. 23, 565-616 (1967)

2. Froesch, E. R., Zapf, J., Meuli, C., Mäder, M., Waldvogel, M., Kaufmann, U., Morell, B.: Biological properties of NSILA-S. Adv. Metab. Disord. 8, 211-235 (1975)

3. Oelz, O., Froesch, E.R., Bünzli, H.F., Humbel, R. E., Ritschard, W.J.: Antibody-suppressible and nonsuppressible insulin-like activities. Handbook of Physiology, Endocrinology, 1, 685-702. Baltimore: Williams and Wilkins Company 1972

4. Rinderknecht, E., Humbel, R. E.: Polypeptides with nonsuppressible insulin-like and cell growth promoting activities in human serum: Isolation, chemical characterization, and some biological properties of forms I and II. Proc. Natl. Acad. Sci. USA 73, 2365-2369 (1976)

5. Rinderknecht, E., Humbel, R. E.: Amino-terminal sequences of two polypeptides from human serum with nonsuppressible insulin-like and cell growth-promoting activities: Evidence for structural homology with insulin B chain. Proc. Natl. Acad. Sci. USA 73, 4379-4381 (1976)

6. Zapf, J., Waldvogel, M., Froesch, E. R.: Binding of nonsuppressible insulin-like activity to human serum. Evidence for a carrier protein. Arch. Biochem. Biophys. 168, 638-645 (1975)

7. Megyesi, K., Kahn, C. R., Roth, J., Gorden, P.: Circulating NSILA-S in man: Preliminary studies of stimuli in vivo and binding to plasma components. J. Clin. Endocrinol. Metab. 41, 475-484 (1975)

8. Meuli, C., Froesch, E. R.: Effects of insulin and of NSILA-S on the perfused rat heart: Glucose uptake, lactate production and efflux of 3-O-methylglucose. Eur. J. Clin. Invest. 5, 93-99 (1975)

9. Meuli, C., Froesch, E. R.: Binding of insulin and nonsuppressible insulin-like activity to isolated perfused rat heart muscle: 
Evidence for two separate binding sites. Arch. Biochem. Biophys. 177, 31-38 (1976)

10. Meuli, C., Froesch, E. R.: Insulin and nonsuppressible insulinlike activity (NSILA-S) stimulate the same glucose transport system via two separate receptors in rat heart. Biochem. Biophys. Res. Commun. 75, 689-695 (1977)

11. Zapf, J., Mäder, M., Waldvogel, M., Schalch, D. S., Froesch, E. R.: Specific binding of nonsuppressible insulin-like activity to chicken embryo fibroblasts and to a solubilized fibroblast receptor. Arch. Biochem. Biophys. 168, 630-637 (1975)

12. Zapf, J., Kaufmann U., Eigenmann, E.J., Froesch, E. R.: Determination of nonsuppressible insulin-like activity in human serum by a sensitive protein-binding assay. Clin. Chem. 23, 677-682 (1977)

13. Froesch, E. R., Bürgi, H., Ramseier, E. B., Bally, P., Labhart, A.: Antibody-suppressible and nonsuppressible insulin-like activities in human serum and their physiologic significance: An insulin assay with adipose tissue of increased precision and specificity. J. Clin. Invest. 42, 1816-1834 (1963)

14. Rasio, E. A., Soeldner, J. S., Cahill, G. F.: Insulin and insulinlike activity in serum and extravascular fluids. Diabetologia $\mathbf{1}$, 125-127 (1965)

15. Partamian, J., Rasio, E., Cahill, G.F.: Studies using the intraperitoneal assay on the state of insulin in rat serum. Metabolism 15, 70-75 (1966)

16. Rasio, E. A., Mack, E., Egdahl, R. H., Herrera, M. G.: Passage of insulin and inulin across vascular membranes in the dog. Diabetes 17, 668-672 (1968)

17. Cohen, K.L., Nissley, S.P.: Comparison of somatomedin activity in rat serum and lymph. Endocrinology 97, 654-658 (1975)
18. Bürgi, H., Müller, W. A., Humbel, R. E., Labhart, A., Froesch, E. R.: Nonsuppressible insulin-like activity of human serum. I. Physicochemical properties, extraction and partial purification. Biochim. Biophys. Acta 121, 349-359 (1966)

19. Kaufmann, U., Zapf, J., Torretti, B., Froesch, E. R.: Demonstration of a specific serum carrier protein of nonsuppressible insulin-like activity in vivo. J. Clin. Endocrinol. Metab. 44, 160-166 (1977)

20. Garlick, D.D., Renkin, E. M.: Transport of large molecules from plasma to interstitial fluid and lymph in dogs. Am. J. Physiol. 219, 1595-1605 (1970)

21. Oelz, O., Jakob, A., Froesch, E. R.: Nonsuppressible insulinlike activity (NSILA) of human serum. V. Hypoglycaemia and preferential metabolic stimulation of muscle by NSILA-S. Eur. J. Clin. Invest. 1, 48-53 (1970)

22. Froesch, E.R., Müller, W. A., Bürgi, H., Waldvogel, M., Labhart, A.: Non-suppressible insulin-like activity of human serum. II Biological properties of plasma extracts with nonsuppressible insulin-like activity. Biochim. Biophys. Acta 121, 360-374 (1966)

Received: August 1, 1977,

and in revised form: November 2, 1977

Dr. E. R. Froesch

Metabolic Unit

Department of Medicine

Kantonsspital

$\mathrm{CH}-809$ Zürich, Switzerland 